\title{
Front Matter: Volume 7083
}

, "Front Matter: Volume 7083," Proc. SPIE 7083, Remote Sensing and Modeling of Ecosystems for Sustainability V, 708301 (3 October 2008); doi: 10.1117/12.815116

SPIE Event: Optical Engineering + Applications, 2008, San Diego, California, United SPIE. States 


\title{
PROCEEDINGS OF SPIE
}

\section{Remote Sensing and Modeling of Ecosystems for Sustainability V}

\author{
Wei Gao \\ Hao Wang \\ Editors
}

13 August 2008

San Diego, California, USA

Sponsored and Published by

SPIE

Cooperating Organizations

USDA UV-B Monitoring and Research Program and Center of Remote Sensing and Modeling for Agricultural Sustainability (USA)

Natural Resource Ecology Laboratory, Colorado State University (USA)

Water Resources Department of China - Institute of Water Resources and Hydropower Research (China)

Key Laboratory of Geo-Information Science of the Ministry of Education at East China Normal University (China)

International Center for Desert Affairs-Research for Sustainable Development in Arid and

Semi-Arid Lands (China)

Volume 7083

Proceedings of SPIE, 0277-786X, v. 7083 
The papers included in this volume were part of the technical conference cited on the cover and title page. Papers were selected and subject to review by the editors and conference program committee. Some conference presentations may not be available for publication. The papers published in these proceedings reflect the work and thoughts of the authors and are published herein as submitted. The publisher is not responsible for the validity of the information or for any outcomes resulting from reliance thereon.

Please use the following format to cite material from this book:

Author(s), "Title of Paper," in Remote Sensing and Modeling of Ecosystems for Sustainability V, edited by Wei Gao, Hao Wang, Proceedings of SPIE Vol. 7083 (SPIE, Bellingham, WA, 2008) Article CID Number.

ISSN 0277-786X

ISBN 9780819473035

Published by

SPIE

P.O. Box 10, Bellingham, Washington 98227-0010 USA

Telephone +1 3606763290 (Pacific Time) · Fax +1 3606471445

SPIE.org

Copyright (c) 2008, Society of Photo-Optical Instrumentation Engineers

Copying of material in this book for internal or personal use, or for the internal or personal use of specific clients, beyond the fair use provisions granted by the U.S. Copyright Law is authorized by SPIE subject to payment of copying fees. The Transactional Reporting Service base fee for this volume is $\$ 18.00$ per article (or portion thereof), which should be paid directly to the Copyright Clearance Center (CCC), 222 Rosewood Drive, Danvers, MA 01923. Payment may also be made electronically through CCC Online at copyright.com. Other copying for republication, resale, advertising or promotion, or any form of systematic or multiple reproduction of any material in this book is prohibited except with permission in writing from the publisher. The CCC fee code is 0277-786X/08/\$18.00.

Printed in the United States of America.

Publication of record for individual papers is online in the SPIE Digital Library.

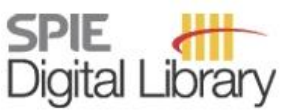

SPIEDigitalLibrary.org

Paper Numbering: Proceedings of SPIE follow an e-First publication model, with papers published first online and then in print and on CD-ROM. Papers are published as they are submitted and meet publication criteria. A unique, consistent, permanent citation identifier (CID) number is assigned to each article at the time of the first publication. Utilization of CIDs allows articles to be fully citable as soon they are published online, and connects the same identifier to all online, print, and electronic versions of the publication. SPIE uses a six-digit CID article numbering system in which:

- The first four digits correspond to the SPIE volume number.

- The last two digits indicate publication order within the volume using a Base 36 numbering system employing both numerals and letters. These two-number sets start with $00,01,02,03,04,05$, 06, 07, 08, 09, OA, OB ... 0Z, followed by 10-1Z, 20-2Z, etc.

The CID number appears on each page of the manuscript. The complete citation is used on the first page, and an abbreviated version on subsequent pages. Numbers in the index correspond to the last two digits of the six-digit CID number. 


\title{
Contents
}

\author{
ix Conference Committee \\ xi Introduction \\ xiii Measurement science for climate remote sensing (Plenary Paper) [7081-53] \\ G. T. Fraser, S. W. Brown, R. U. Datla, B. C. Johnson, K. R. Lykke, J. P. Rice, National Institute \\ of Standards and Technology (United States
}

\section{SESSION 1 REMOTE SENSING THEORY, TECHNIQUES, AND APPLICATIONS I}

708302 Microwave vegetation indices derived from satellite microwave radiometers (Invited Paper) [7083-01]

T. J. Jackson, U.S. Dept. of Agriculture (United States); J. C. Shi, Univ. of California, Santa Barbara (United States); J. Tao, Beijing Normal Univ. (China)

\section{SESSION 2 REMOTE SENSING THEORY, TECHNIQUES, AND APPLICATIONS II}

708305 Object-based algorithms and methods for quantifying urban growth pattern using sequential satellite images [7083-06]

B. YU, East China Normal Univ. (China) and Texas A\&M Univ. (United States); H. Liu, Y. Gao, Texas A\&M Univ. (United States); J. Wu, East China Normal Univ. (China)

708306 Summer to autumn changes in vegetation spectral indices of deciduous trees [7083-07]

J. Cipar, T. Cooley, R. Lockwood, Air Force Research Lab. (United States)

708307 Obtaining three-dimensional forest canopy structure using TLS [7083-08]

Z. Ling, Beijing Normal Univ. (China) and Institute of Geographic Sciences and Natural

Resources Research (China); Z. Jie, Beijing Normal Univ. (China)

\section{SESSION 3 REMOTE SENSING THEORY, TECHNIQUES, AND APPLICATIONS III}

708309 Use of MODIS satellite images to investigate the chlorophyll-a concentrations in Lake Okeechobee, Florida [7083-66]

A. Makkeasorn, C.-H. Cheng, N.-B. Chang, Univ. of Central Florida (United States)

7083 OC Mapping underwater topography for coastal estuary ecosystem monitoring from QuickBird high-resolution multispectral imagery [7083-13]

M. Ji, Guangxi Academy of Sciences (China) and East China Normal Univ. (China);

Z. Deng, Y. Wu, East China Normal Univ. (China); Y. Peng, F. Lei, Guangxi Academy of Sciences (China)

7083 OD Land cover dynamic monitoring model of Three Gorges area [7083-14]

L. Zhu, Chongqing Technology and Business Univ. (China); Y. Tian, W. Zhou, Southwest Univ. (China) 
$7083 \mathrm{OH}$ Assessing the impact of future climate change on wheat production in Huang-Huai-Hai Plain in China based on GIS and crop model [7083-04]

Z. Tian, J. Shi, Shanghai Climate Ctr. (China); Z. Gao, Institute of Geographical Sciences and Natural Resources Research (China) and East China Normal Univ. (China);

F. N. Tubiello, International Institute for Applied Systems Analysis (Austria)

7083 ol Application of eco-economy regionalization in western China [7083-18]

$X$. Zhang, Beijing Union Univ. (China) and Institute of Geographical Sciences and Natural Resources Research (China); S. Dong, Institute of Geographical Sciences and Natural Resources Research (China); Y. Weihong, Beijing Union Univ. (China)

$70830 \mathrm{~J}$ Research response of land surface water and heat flux to land use land cover changes in Laizhou Bay [7083-19]

$X$. Zhou, Institute of Geographical Sciences and Natural Resources Research (China) and Graduate School of the Chinese Academy of Sciences (China); X. Cao, Xinjiang Institute of Ecology and Geography (China) and Graduate School of Chinese Academy of Sciences (China); M. Chen, Institute of Geographical Sciences and Natural Resources Research (China) and Graduate School of Chinese Academy of Sciences (China); Z. Gao, Institute of Geographical Sciences and Natural Resources Research (China)

7083 OK Land surface temperature in response to land use/cover change based on remote sensing data in Sangong River [7083-20]

X. Cao, Xinjiang Institute of Ecology and Geography (China) and Graduate School, Chinese Academy of Sciences (China); A. Bao, Xinjiang Institute of Ecology and Geography (China) and Beijing Normal Univ. (China); X. Chen, Xinjiang Institute of Ecology and Geography (China); Y. Xia, Xinjiang Institute of Ecology and Geography (China) and Graduate School, Chinese Academy of Sciences (China)

$7083 \mathrm{OL}$ Improvements of regional evapotranspiration model by considering topography correction [7083-21]

C. Liu, East China Normal Univ. (China); W. Gao, East China Normal Univ. (China) and Colorado State Univ. (United States); Z. Gao, East China Normal Univ. (China), Colorado State Univ. (United States), and Institute of Geographical Sciences and Natural Resources Research (China); S. XU, East China Normal Univ. (China)

7083 OM The comparing study of net primary production in China [7083-22]

Z. Gao, Institute of Geographical Sciences and Natural Resources Research (China), East China Normal Univ. (China) and Colorado State Univ. (United States); X. Cao, Xinjiang Institute of Ecology and Geography (China) and Graduate School of Chinese Academy of Sciences (China); M. Chen, Institute of Geographical Sciences and Natural Resources Research (China), East China Normal Univ. (China), and Colorado State Univ. (United States); W. Gao, East China Normal Univ. (China) and Colorado State Univ. (United States)

708300 Estimation of land photosynthetically active radiation in clear sky using MODIS atmosphere and land products [7083-24]

$X$. Xie, Nanjing Univ. of Information Science \& Technology (China) and Institute of Geographical Sciences and Natural Resources Research (China); W. Gao, Colorado State Univ. (United States); Z. Gao, Institute of Geographical Sciences and Natural Resources Research (China) and Colorado State Univ. (United States) 
7083 OP A method for estimating the incident PAR on inclined surfaces [7083-25]

$X$. Xie, Nanjing Univ. of Information Science \& Technology (China) and Institute of Geographical Sciences and Natural Resources Research (China); W. Gao, Colorado State Univ. (United States); Z. Gao, Institute of Geographical Sciences and Natural Resources Research (China) and Colorado State Univ. (United States)

7083 OQ Landscape pattern change research of land use about the Baiyang River in Fukang based on fractal theory [7083-26]

X. Cao, Xinjiang Institute of Ecology and Geography (China) and Graduate School of The Chinese Academy of Sciences (China); A. Bao, Xinjiang Institute of Ecology and Geography (China) and Beijing Normal Univ. (China); X. Chen, Xinjiang Institute of Ecology and Geography (China); Y. Xia, Xinjiang Institute of Ecology and Geography (China) and Graduate School of The Chinese Academy of Sciences (China)

7083 OR Study on models for monitoring of above ground biomass about Bayinbuluke grassland assisted by remote sensing [7083-27]

A. Bao, Beijing Normal Univ. (China) and Xinjiang Institute of Ecology and Geography (China); X. Cao, Xinjiang Institute of Ecology and Geography (China) and Graduate School, Chinese Academy of Sciences (China); X. Chen, Xinjiang Institute of Ecology and Geography (China); Y. Xia, Xinjiang Institute of Ecology and Geography (China) and Graduate School, Chinese Academy of Sciences (China)

7083 OS Features of the large-scale circulation of the extremely heavy rain with severe floods over South China in June 2005 and its possible cause [7083-28]

L. Wang, Z. Guan, C. Shi, Nanjing Univ. of Information Science \& Technology (China); J. Tao, Yangzhou Meteorological Bureau (China); L. Jin, Nanjing Univ. of Information Science \& Technology (China)

7083 ОT The comparative experiments on ensemble prediction based on two groups of initial conditions [7083-33]

Y. Guan, Nanjing Univ. of Information Science \& Technology (China) and Institute of Atmospheric Physics (China); W. Lu, Nanjing Univ. of Information Science \& Technology (China); G. Zhou, Institute of Atmospheric Physics (China)

$70830 X$ Responses of plant biochemical substances to reflectance spectra at leaf and canopy scales [7083-38]

R. Shi, East China Normal Univ. (China) and Institute of Geographical Sciences and Natural Resources Research (China); H. Zhang, J. Sun, East China Normal Univ. (China); W. Gao, East China Normal Univ. (China) and Colorado State Univ. (USA); D. Zhuang, Institute of Geographical Sciences and Natural Resources Research (China); Z. Niu, Institute of Remote Sensing Applications (China)

7083 OY Mapping mangroves from high-resolution multispectral imagery: using Beilun Estuary, Guangxi, China as a case study [7083-39]

M. Ji, Guangxi Academy of Sciences (China) and East China Normal Univ. (China); Y. WU, Z. Deng, East China Normal Univ. (China); H. Fan, Guangxi Mangrove Research Ctr.

(China); Z. Zhang, East China Normal Univ. (China) 
708311 Summer rain band pattern in mid-lower reaches of Yangtze River and its inter-decadal variability [7083-45]

A. Pan, Nanjing Univ. of Information Science \& Technology (China) and Jiangsu Provincial Meteorological Bureau (China); Z. Sun, N. Du, Q. Gao, Nanjing Univ. of Information Science \& Technology (China)

708312 Model of root system for winter wheat and water uptake [7083-46]

W. Fang, R. Liu, Z. Zhu, Henan Institute of Meteorological Sciences (China); T. Deng, Henan Meteorological Administration (China)

708313 Comparison of in situ station data and reanalysis data in winter and summer temperature in China [7083-47]

Q. Gao, Z. Guan, N. Du, Nanjing Univ. of Information Science \& Technology (China); T. Hu, Chinese Meteorological Administration (China)

708314 Numerical simulation by the Common Land Model (CLM) of the soil moisture over China during the summer of 2006 [7083-48]

L. Zou, Shanghai Meteorological Ctr. (China); W. Gao, Colorado State Univ. (United States); T. WU, Q. LU, Y. Zhang, Chinese Meteorological Administration (China)

708315 Analysis of ecological vulnerability based on landscape pattern and ecological sensitivity: a case of Duerbete County [7083-49]

M. Jiang, Peking Univ. (China); W. Gao, Colorado State Univ. (United States); X. Chen, $X$. Zhang, Peking Univ. (China); W. Wei, Peking Univ. (China) and Light Industry Environment Protection Institute (China)

708316 Analysis on causes/evolution of floods over the Songhua main stream basin and the properties of the 1998 deluge over the Song-Nen Plain [7083-50]

N. Xu, Nanjing Univ. of Information Science \& Technology (China) and Heilongjiang Meteorological Administration (China); P. Guo, Nanjing Univ. of Information Science \& Technology (China); G. Zhang, M. Yuan, H. Pan, Heilongjiang Provincial Meteorological Observatory (China)

708317 Spatio-temporal distributions of meso convective systems in NE China and its vicinity [7083-51]

M. Yuan, Nanjing Univ. of Information Science \& Technology (China) and Provincial Meteorological Observatory of Heilongjiang (China); Z. Li, X. Zhang, National Meteorological Ctr. (China); X. Li, Nanjing Univ. of Information Science \& Technology (China)

7083 1B Estimation of soil moisture of winter wheat fields in Henan Province of China [7083-56] G. Zhao, Henan Institute of Meteorological Science (China) and Henan Bureau of Meteorology (China); T. Deng, S. Wang, Henan Bureau of Meteorology (China); L. Cheng, J. Wang, Henan Institute of Meteorological Science (China); X. Wang, Colorado State Univ. (United States)

7083 1C The impacts of radiation effects of atmospheric aerosol on rice production in the Yangtze Delta Region [7083-57]

W. Zhai, Chinese Academy of Meteorological Sciences (China); Y. Zhao, Chinese Academy of Meteorological Sciences (China) and China Meteorological Administration (China); C. Wang, Chinese Academy of Meteorological Sciences (China); X. Xia, Institute of Atmospheric Physics (China); X. XU, China Meteorological Administration (China) 
7083 1D The application of Modified Perpendicular Drought Index (MPDI) method in drought remote sensing monitoring [7083-58]

H. Zhang, Nanjing Univ. of Information Science \& Technology (China), Meteorological Bureau of XinXiang (China), and Henan Institute of Meteorology (China); H. Chen, Henan Institute of Meteorology (China); S. Shen, Nanjing Univ. of Information Science \& Technology (China); C. Zou, Henan Institute of Meteorology (China)

7083 IE Evaluation of soil erosion risk in Karst regions of Chongqing, China [7083-59] W. Zhou, S. Xie, Southwest Univ. (China); L. Zhu, Chongqing Technology and Business Univ. (China); Y. Tian, J. Yi, Southwest Univ. (China)

7083 IF Remote sensing-based research of urban thermodynamic landscape heterogeneity and spatial scale effect [7083-60]

J. Yi, Y. Tian, Southwest Univ. (China); L. Zhu, Chongqing Technology and Business Univ. (China); Y. Gao, Chongqing Institute of Meteorological Science (China); B. Wang,

Southwest Univ. (China)

7083 IG Analyzing the 2007 drought of Poyang Lake Watershed with MODIS-derived Normalized Difference Water Deviation Index [7083-61]

W. Zhang, Sichuan Univ. (China); X. Cao, Xinjiang Institute of Ecology and Geography (China); J. Peng, Peking Univ. (China)

7083 1H Simulations of IPCC SRES effect upon winter wheat growing in the Chinese Huang-Huai valley [7083-63]

S. Li, L. Cheng, R. Liu, Henan Institute of Meteorological Sciences (China); X. Wang,

Colorado State Univ. (United States)

7083 IL Estimating winter wheat biomass based on LANDSAT TM and MODIS data [7083-68]

Y. Bao, Nanjing Univ. of Information Science \& Technology (China), Colorado State Univ. (United States), and East China Normal Univ. (China); W. Gao, Colorado State Univ. (United States) and East China Normal Univ. (China); Z. Gao, Colorado State Univ. (United States), East China Normal Univ. (China), and Institute of Geographical Sciences and Natural Resources Research (China)

Author Index 
Downloaded From: https://www.spiedigitallibrary.org/conference-proceedings-of-spie on 26 Apr 2023

Terms of Use: https://www.spiedigitallibrary.org/terms-of-use 


\title{
Conference Committee
}

\author{
Program Track Chair
}

Allen H. L. Huang, University of Wisconsin, Madison (United States)

Conference Chair

Wei Gao, Colorado State University (United States)

Conference Cochair

Hao Wang, China Institute of Water Resources and Hydropower Research (China)

Program Committee

Gregory P. Asner, Stanford University (United States)

Xiuwan Chen, Peking University (China)

John A. Gamon, California State University, Los Angeles (United States)

E. Raymond Hunt, Jr., USDA Agricultural Research Service (United States)

John M. Melack, University of California, Santa Barbara (United States)

Dennis Ojima, Colorado State University (United States)

Jeffrey L. Privette, NASA Goddard Space Flight Center (United States)

Jiaguo Qi, Michigan State University (United States)

John Jianhe Qu, George Mason University (United States)

Daniel L. Schmoldt, U.S. Department of Agriculture (United States)

Jiong Shu, East China Normal University (China)

James R. Slusser, Colorado State University (United States)

Susan L. Ustin, University of California, Davis (United States)

Denghua Yan, China Institute of Water Resources and Hydropower Research (China)

Hua Zhang, National Climate Center (China)

\section{Session Chairs}

1 Remote Sensing Theory, Techniques, and Applications I

Thomas J. Jackson, U.S. Department of Agriculture (United States)

2 Remote Sensing Theory, Techniques, and Applications II

Jiong Shu, East China Normal University (China)

John J. Cipar, Air Force Research Laboratory (United States) 
3 Remote Sensing Theory, Techniques, and Applications III

E. Raymond Hunt, Jr., USDA Agricultural Research Service (United States)

Minhe Ji, East China Normal University (China) 


\section{Introduction}

These proceedings comprise papers presented during the conference titled Remote Sensing and Modeling of Ecosystems for Sustainability $V$, which was held in San Diego, California, USA, 13 August 2008, as part of SPIE's annual Optics + Photonics Symposium. This conference was designed to focus on the ecosystems remote sensing and modeling theory, techniques, and applications. There were over 40 presentations delivered in the sessions of oral presentations and poster presentations. This conference provided a great opportunity for scientists from different countries to exchange scientific ideas and discuss their latest research. Papers were reviewed and edited by conference chairs and conference program committee members with help from Ms. Laurie Richard, Mr. William Smith, USDA UV-B supporting staff Rita Deike, and SPIE editorial staff. Special thanks goes to the USDA UV-B Monitoring and Research Program and Center of Remote Sensing and Modeling for Agricultural Sustainability, Natural Resource Ecology Laboratory (NREL) at Colorado State University, Water Resources Dept. of China Institute of Water Resources and Hydropower Research, the Key Laboratory of Geo-Information Science of the Ministry of Education at East China Normal University, and International Center for Desert Affairs-Research for Sustainable Development in Arid and Semi-arid Lands, who served as cooperating organizations. The conference owes its success to the diligent efforts of the SPIE technical staff, and Dr. Daniel Schmoldt, project manager of USDA/CSREES, for their continued guidance and support.

We would like to extend our appreciation to the outstanding program committee, the session chairs, and especially the authors for their contributions to this successful conference.

Wei Gao 